\title{
Enhancing the Performance of Photovoltaic Panel by Proper Washing Periods in Kuwait
}

\author{
Hussain Bunyan, Wesam Ali, Mahmud Alnaser \\ Electronics Department, College of Technological Studies, Public Authority of Applied Education \\ and Training, Kuwait City, Kuwait \\ Email: ha.bunyan@paaet.edu.kw
}

Received 1 May 2016; accepted 12 June 2016; published 15 June 2016

Copyright $(2016$ by authors and Scientific Research Publishing Inc.

This work is licensed under the Creative Commons Attribution International License (CC BY).

http://creativecommons.org/licenses/by/4.0/

c) (i) Open Access

\begin{abstract}
Dust and impurity accumulation has a significant effect on the efficiency and performance of PV panel output power. It influences the transmittance of solar radiation from the PV panels surface. Scheduling weekly or monthly cleaning periods requires complete knowledge of area's weather and environmental condition. In this study, an experimental-based investigation is conducted aiming for a proper scheduling cleaning periods by comparing the output power efficiency of two identical PV panels, the first being cleaned daily and the other cleaned monthly. Both are exposed to unstable weather condition with Sarayat season in April and May, winter and summer Shamal of Kuwait for one year. The results indicated a significant degradation of PV panel output power in April, May, October and December. A need for frequent weekly water washing is a necessity to maintain the power efficiency loss of $15.07 \%, 13.74 \%, 10.685 \%$ and $8.742 \%$ respectively, and frequent monthly water washing for the remaining months of the year.
\end{abstract}

\section{Keywords}

PV Panel, Impurity Deposition, Efficiency, Effect of Dust, Deficiency, Output Power

\section{Introduction}

The abundance of sunlight throughout the year is what makes the desert countries fertile area to photovoltaic power generation, but the PV panel's performance is affected by the accumulation of dust particles on its surface.

Dust is a major environmental factor which affects the PV panel performance. Many researchers investigated the performance of PV panel with dust concentration on the surface in $\mathrm{g} / \mathrm{m}^{2}$. The efficiency of a PV panel was decreased by $0.4 \%$ as dust density increased to $0.09 \mathrm{mg} / \mathrm{cm}^{2}$ [1]. Results of PV panel behavior with dust deposi-

How to cite this paper: Bunyan, H., Ali, W. and Alnaser, M. (2016) Enhancing the Performance of Photovoltaic Panel by Proper Washing Periods in Kuwait. Smart Grid and Renewable Energy, 7, 190-196. 
tion on its surface show a decrease of efficiency up to $92 \%$ and $89 \%$ respectively compared to a clean PV panel [2].

To avoid deficiency of PV panel performance by dust accumulation, it is important to study environmental and weather conditions of installation area, which indicates how frequent the PV panel has to be cleaned.

Kuwait environmental and weather conditions:

Kuwait is 17,818 square kilometers, situated at the extreme northwestern end of the Arabian Gulf between latitudes $28^{\circ} 30^{\prime}$ and $30^{\circ} 05^{\prime}$ north and longitudes $46^{\circ} 33^{\prime}$ and $48^{\circ} 36^{\prime}$ east; it is bounded to the north and west by Iraq, to the south by Saudi Arabia, and the east by the Arabian Gulf. The terrain of Kuwait is flat or gently undulating, rising to the height of 271 meter in the extreme southwest of the country.

The climate of Kuwait in general is characterized by very hot, dry summers and cool rainy winters. The average annual rainfall in Kuwait city is about $111 \mathrm{~mm}$, but other parts of the country receive as little as $23 \mathrm{~mm}$ or as much as $206 \mathrm{~mm}$. Most of the rainfall occurs as light winter showers brought about by westerly depressions. Summer temperature are extremely high, often exceeding $45^{\circ} \mathrm{C}$ during June, July and august. In winter, temperature often rises to over $20^{\circ} \mathrm{C}$ during the day, but then fall rapidly at night when frosts are not uncommon, especially inland. The humidity is generally high and often exceeds $90 \%$. Dust and sand storms are common throughout the year [3].

The climate in Kuwait goes throughout some unusual seasons which are known as:

1) Sarayat season, starts at April usually the onset of unstable weather condition, can be characterized by sudden changes in the weather day by day from sunny, dusty to thunderstorms, and even with hailstorm at times.

2) Shamal season, the term "Shamal" means north in Arabic. It refers to the prevailing wind direction from which this type of dust storm is produced. Shamal dust storms occur across Iraq, Kuwait, and the Arabian Peninsula. They generate a tremendous amount of dust in the atmosphere. The winds travel across central and southern Iraq, picking up most of the dust load from source areas in southern portion of Iraq between the Tigris and Euphrates Rivers. There are two types of "Shamal”: winter and summer [4].

The winter Shamal, occurs mainly between November and March and is directly associated with mid-latitude disturbances moving from west to east. They are caused by the presence of a large pressure gradient that develops behind a cold front passage. Upper level subsidence and rapidly building high pressure over Saudi Arabia and Iraq reinforces the low-level northwesterly winds. Based on duration, there are two types of winter Shamal: those which last 24 - $36 \mathrm{~h}$ and those which last for a longer period of 3 - 5 days. During Shamal, winds typically reach 15 - 20 m s-1 near the surface during day time. A Shamal occurs first in the northwestern part of the gulf and then spreads southeast behind the advancing cold front. Moderate to strong winds can raise desert surface material and reduce visibility. Shamal wind generated storm surges, coupled with tidal effects can lead to significant changes in the sea level of several meters [5].

The summer shamal, blows almost daily during the summer months of June through September. In Kuwait, the shamal is known as "simoom", which means poison wind. The synoptic feature that creates the potential for the shamal is a zone of convergence between the subtropical ridge extending into the northern Arabian Peninsula and Iraq from the Mediterranean Sea and Monsoon trough across southern Iran and southern Arabian Peninsula [4].

Impurities are major problem with solar panels, and letting them accumulate will reduce a solar panel's efficiency by almost 25 - 30 percent even in dust-free Europe. It is therefore essential to maintain them with regular periodic cleaning.

The impact of impurities on PV solar panels can be categorized as follows:

1) The dusty raining days of Sarayat season, producing sticking clay on the panels.

2) The dust produced from the winter or summer Shamal season.

3) The road dirt and dust produced by vehicles on nearby dirt roads, or the left of asphalt and outlets of vehicles.

4) Bird droppings, flock of birds leave behind a mess after bypassing the panel area over night.

This study investigates the effect of dust and impurity accumulation on the performance of PV panels and how often it should be cleaned in Kuwait. Due to the fact that Kuwait is a desert country with dusty weather, the effect of impurities on PV panels cannot be ignored.

\section{Experimental Setup and Methodology}

Two symmetrical monocrystalline PV module (model SM55, Siemens) with a rating of 55W maximum power 
were placed at a fixed tilt angle of $30^{\circ}$ with horizontal plane facing south. Technical specifications and physical dimensions of the PV module used in this study are shown in Table 1.

A pyranometer TB is used to measure the global solar radiation (GSR) in plane with the PV module. A technical specification of the pyranometer is shown in Table 2. Measurements of Current (I), voltage (v), ambient temperature $(\mathrm{T})$ taken by connecting the system to a data acquisition system model (Datataker DT80) which controlled by a PC, Figure 1, illustrates the schematic of experimental setup. Continuous measurements were carried out during the day from 6 Am to 6 PM with a time intervals of one hour. All the data collected were synchronized for data processing.

The panels are exposed in the atmospheric environment over one year period. One panel is cleaned dally early in the morning with running water and a clean cloth. The second panel is carefully cleaned monthly; the total mass of the pollutants accumulated on the surface is measured with the use of a very precise digital weighing balance of $0.1 \mathrm{mg}$ accuracy and a dehumidifier.

The steps of the experimental procedure are as follows:

- One meter of soft tissue paper and a polystyrene cup are used in order clean the PV panel (Figure 2).

- The paper tissue and the polystyrene cup are weighed with a digital balance and recorded as mass of tissue cup clean $\left(m_{c l}\right)$.

- The hard particles (i.e. bird droppings) are removed and placed in polystyrene cup (Figure 3(a)).

- The paper tissue is wetted with filtered water in order to be used for the PV panel cleaning.

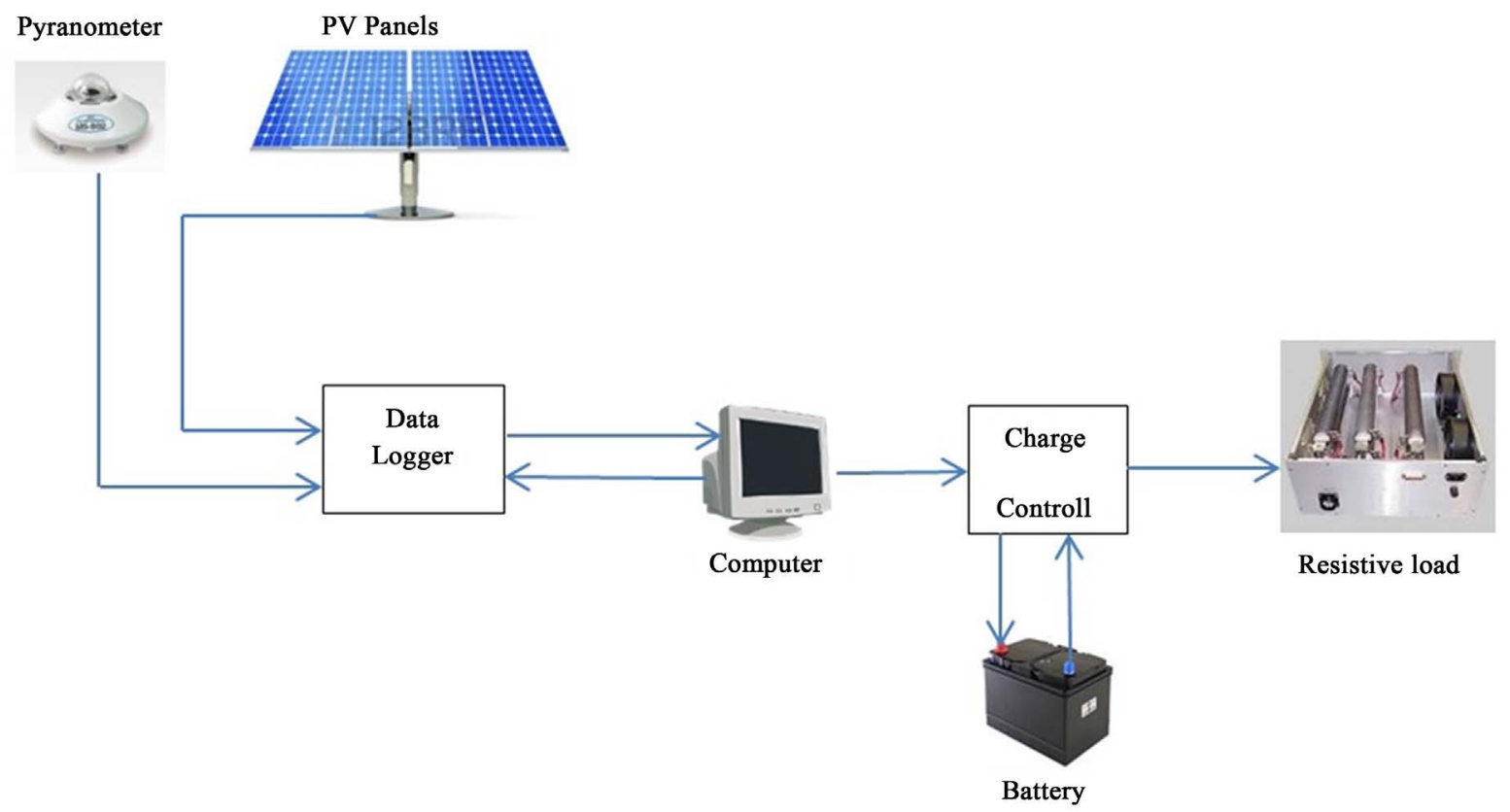

Figure 1. Illustrates the schematic of experimental setup.

Table 1. Typical electrical parameters for experimental PV module.

$\begin{array}{cc}\text { Maximum power rating } \mathrm{P}_{\max }(\mathrm{W}) & 55 \\ \text { Maximum power current } \mathrm{I}_{\mathrm{MPP}}(\mathrm{A}) & 3.15 \\ \text { Maximum power voltage } \mathrm{V}_{\mathrm{MPP}}(\mathrm{V}) & 17.4 \\ \text { Short circuit current } \mathrm{I}_{\mathrm{SC}}(\mathrm{A}) & 3.45 \\ \text { Open circuit voltage } \mathrm{V}_{\mathrm{OC}}(\mathrm{V}) & 21.7 \\ \text { Short circuit temp coefficient }\left(\mathrm{mA} /{ }^{\circ} \mathrm{C}\right) & 1.2 \\ \text { Open circuit voltage coefficient }\left(\mathrm{V} /{ }^{\circ} \mathrm{C}\right) & 0.77\end{array}$

Standard test conditions (defined as: irradiation $=1000 \mathrm{~W} / \mathrm{m}^{2}$; cell temperature $=25^{\circ} \mathrm{C}$; air mass $=1.5$ ). 


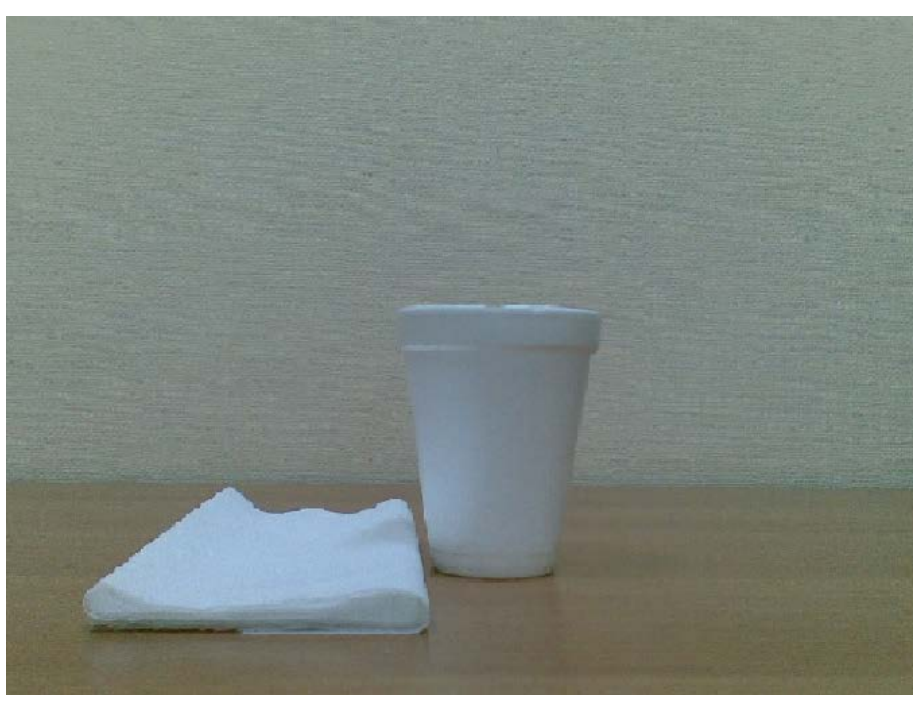

Figure 2. A clean one meter of soft tissue paper and a polystyrene cup.

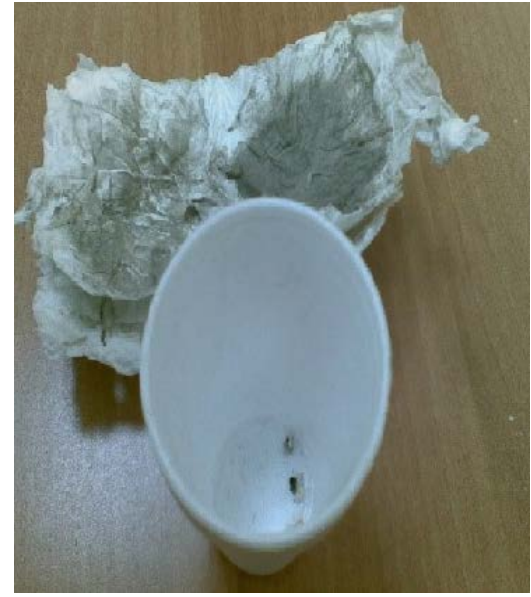

(a)

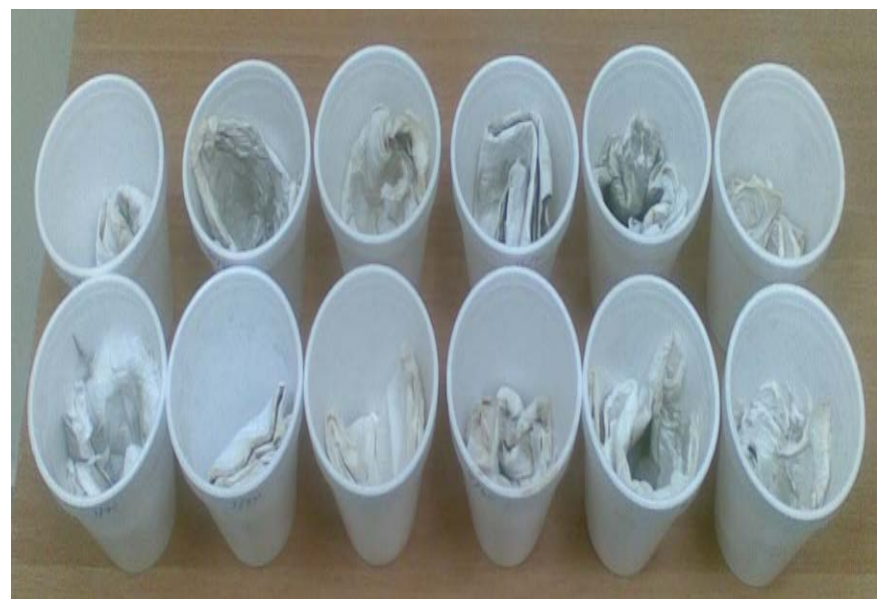

(b)

Figure 3. (a) Unclean polystyrene cup showing bird droppings and used paper tissue, (b) 12 used paper tissue and polystyrene cups.

Table 2. Pyranometer (PSP) parameters.

$\begin{array}{ccc}\text { Sensitivity } & \left(\mathrm{W} / \mathrm{m}^{2}\right) & 9 \mu \mathrm{V} \\ \text { Impedance } & (\mathrm{Ohms}) & 650 \\ \text { Temperature dependence } & (\mathrm{C}) & 1 \% \text { over }-20+40 \\ \text { Linearity } & \left(\mathrm{W} / \mathrm{m}^{2}\right) & \pm 0.5 \% \text { from } 0 \text { - } 2800 \\ \text { Response time } & (\mathrm{S}) & 1 \text { (for a } 1 / \mathrm{e} \text { relaxation) } \\ \text { Cosine response } & (\text { Degree }) & 1 \% \text { for } 0 \text { - } 70 \text { (from zenith) }\end{array}$

- The PV panel is cleaned vertically up word to make sure that none of the impurities are lost.

- The paper tissue and the polystyrene cup are kept to dry completely in the dehumidifier, weighed and recorded as mass of tissue cup with impurities $\left(m_{i m}\right)$ (Figure $3(\mathbf{b})$ ).

- The difference of weighed values before and after the cleaning is the total mass of impurity deposition on the surface of the polluted panel: 


$$
\Delta m=m_{i m}-m_{c l}
$$

The impurity deposition density $(\Delta M)$ is expressed in $\mathrm{g} / \mathrm{m}^{2}$, via the PV panel area $(A)$ as:

$$
\Delta M=\frac{\Delta m}{A}
$$

Taking in consideration, the impact of pollution on the efficiency of the PV panel, and the relation between the efficiency of PV panel and impurity deposition (mass per area unit) on the surface using the experimental measurements, thus:

The energy efficiency $(\eta)$ of the PV panel is given as the ratio between the produced output power $\left(P_{\text {out }}\right)$ and the solar power $\left(P_{\text {solar }}\right)$ at the surface of the PV panel (area of solar panel) $(A)$.

$$
\eta=\frac{P_{\text {out }}}{P_{\text {solar }}}=\frac{V \cdot I}{A G}
$$

where $V$ and $I$ are the voltage and current output of the PV panel respectively, $G$ is the solar irradiation.

To analyze the efficiency of impurities on the PV panel specifically, we will investigate the efficiency of the $\mathrm{PV}$ panel compared to the rated output power:

$$
\eta_{\text {spec }}=\frac{P_{\text {out }}}{P_{\text {rated }}} \frac{V \cdot I}{V_{\text {oc }} I_{\text {sc }}}
$$

where $\eta_{\text {spec }}$ specific efficiency, $V_{o c}$ and $I_{s c}$ are rated open circuit voltage and rated short circuit current respectively.

From that the defficieny $(\psi)$ of PV panel is:

$$
\psi=1-\frac{P_{\text {out }}}{P_{\text {rated }}}=1-\frac{V \cdot I}{V_{\text {oc }} I_{\text {sc }}}
$$

Finally, in order to investigate for maximum power loss because of polluted PV panel during the year, we look into the deficiency and the impurity deposition density data, and thus examine if $\Delta M$ and $\Psi$ match.

\section{Results and Discussion}

One of the major problems facing PV panels is impurity accumulation, it is been proved by numerous researchers that more than $50 \%$ of the solar module performance reduction caused by unclean solar module for a period of one month [6].

Scheduling cleaning period requires complete knowledge of area's environmental condition, which various depending on the location. Therefore it is important to study the environment and weather of target location before an installation of solar system.

In this study a series of measurements concerning the two identical PV panels was carried out by the data acquisition system (data taker) every hour from 6 AM to 6 PM for one calendar year. The daily cleaned PV panel performance was compared with that of polluted one. The data acquisition system recorded the voltage and current of the PV panels along with the values of solar radiation $\left(\mathrm{W} / \mathrm{m}^{2}\right)$, temperature, humidity and wind velocity were recorded as will.

All the data collected were synchronized for data processing, the efficiency and deficiency of PV panel were calculated.

According to the data collected the measured dust deposition density throughout the experiment varied from 0.00821 to $0.0422 \mathrm{mg} / \mathrm{cm}^{2}$, quantities which correspond to the most clean month (i.e. November) and the most unclean month (i.e. April) of the polluted PV panel which was outdoors exposure to natural air pollution.

The distribution of impurity on PV panel for one calendar year is demonstrated in Figure 4. It can be observed that the variation of impurity accumulation increased above the average in April, May, October and December by $90 \%, 72 \%, 27.4 \%$, and $11.26 \%$ respectively and decrease below average in November and June by $63 \%$ and $61.5 \%$ respectively due to change in weather condition. Figure 5 explains the correlation between the deposited accumulated impurity on the surface of the PV panel and its efficiency for daily cleaned and monthly clean panels. Comparing between the efficiency of the two panels it can be seen that the efficiency of monthly cleaned PV panel decreased because of dust accumulation in April, May, October, and December by 15.072\%, $13.742 \%, 10.685 \%$ and $8.742 \%$ respectively and no effect occurred on the efficiency in November and June. Figure 6 demonstrates the deficiency of the unclean PV panel and the impurity deposition density during the 
Impurity/Month

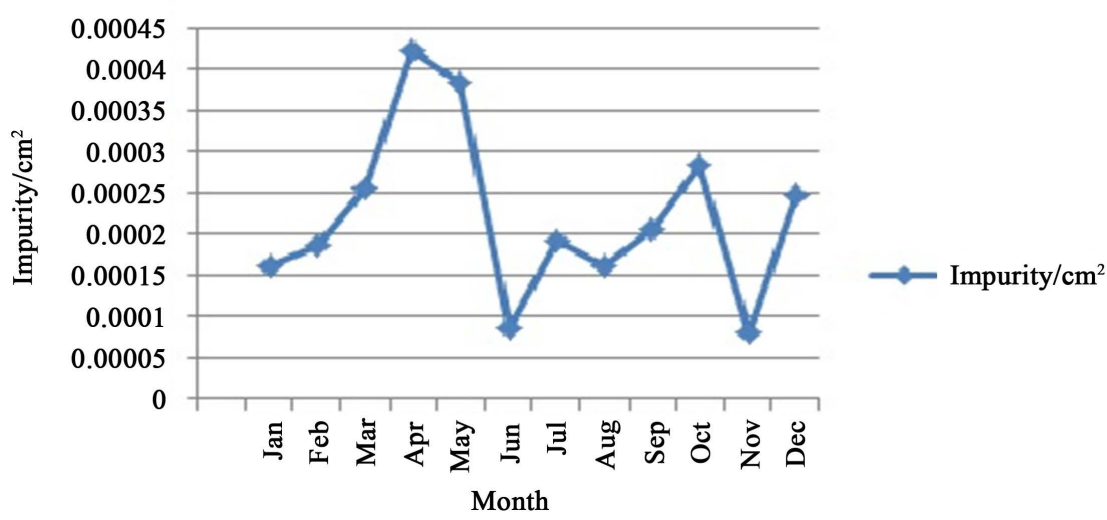

Figure 4. Impurity deposition per month.

Efficiency difference \%

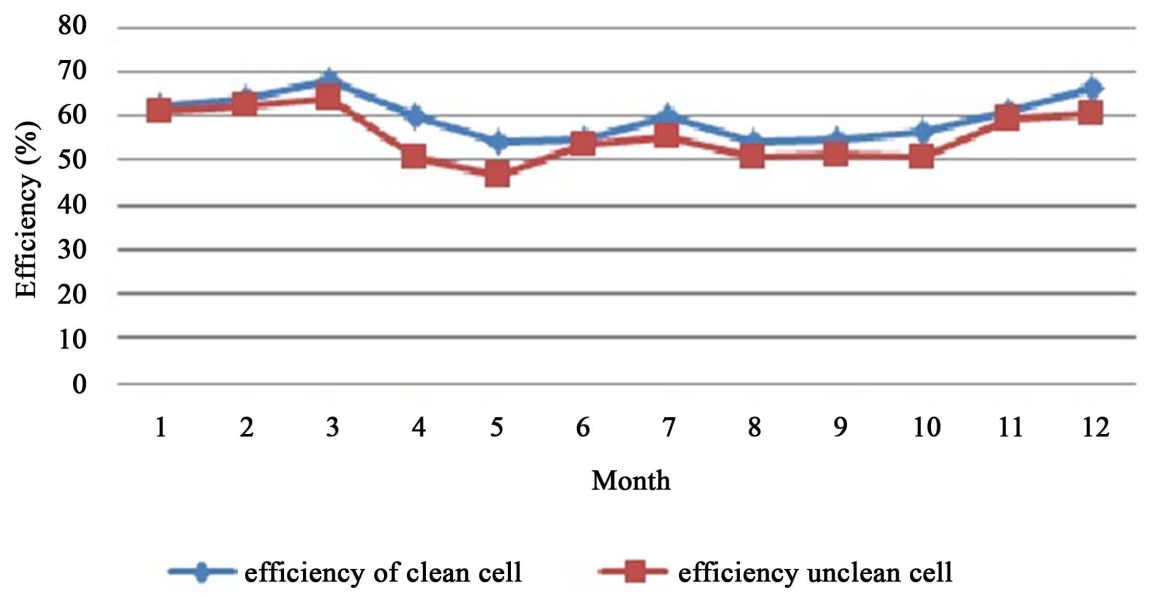

Figure 5. Efficiency of monthly cleaned and dally cleaned PC panels.

Deficiency \& Impurity deposition Density

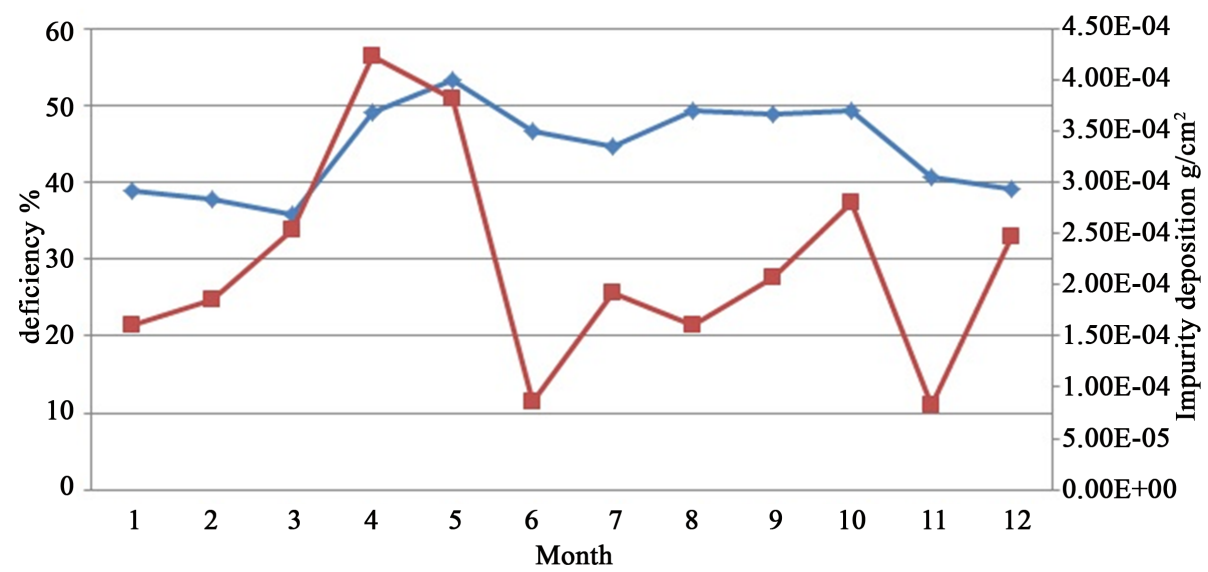

$\leadsto$ deficiency $\rightarrow$ impurity deposition density

Figure 6. Deficiency and impurity deposition density. 
year; we can observe the proportionality of PV panel's output deficiency and the impurity deposition, which sports the necessity of weekly cleaning periods for months with high level of impurity deposition and cleaning periods for months with less level of impurity deposition.

\section{Conclusions}

The impurity effect on performance of PV panel was investigated. The PV panels were exposed to the real outdoor weather condition of Kuwait for one year. The monthly dust deposition density on the PV panel surface throughout the experiment varied from 0.00821 to $0.0422 \mathrm{mg} / \mathrm{cm}^{2}$.

A significant degradation of PV panel efficiency was noticeable under the effect of dust deposition in April, May, October and December by $15.07 \%, 13.74 \%, 10.685 \%$ and $8.742 \%$ respectively compared to the daily cleaned PV panel.

Complete knowledge of area's weather and environmental condition, helps to schedule weekly cleaning period for months with high level of deposition i.e. April, May, October and December, and monthly cleaning period for months with less deposition level i.e. January, February, Jun and November to reduce the dirt and debris accumulated.

\section{References}

[1] Kaldellis, J.K., Kokala, A. and Kapsali, M. (2010) Natural Air Pollution Deposition Impact on the Efficiency of PV Panels in Urban Environment. Fresenius Environmental Bulletin PSP, 19, 2864-2872.

[2] Rajut, D.S. and Sudhakar, K. (2013) Effect of Dust on the Performance of Solar PV Panel. International Journal of Chem Tech Research, 5, 1083-1086.

[3] http://www.readbag.com/ramsar-wetlands-portals-15-kuweait

[4] MSGT Walter D., Wilkerson AFGWC/DOF (1991) Dust and Sand Forecasting in Iraq and Adjoining Countries.

[5] Prassad, G. Thoppil, Patrick J. Hogan, (2010) Persian Gulf Response to Winter Shamal Wind Event. Science Direct, 57, 946-955.

[6] Omar, A. and Hasan, A. (2012) Effect of Dust Accumulation on Performance of Photovoltaic Solar Modules in Sahara Environment. Journal of Basic and applied scientific Research, 2, 11030-11036. 